\title{
Processing French
}





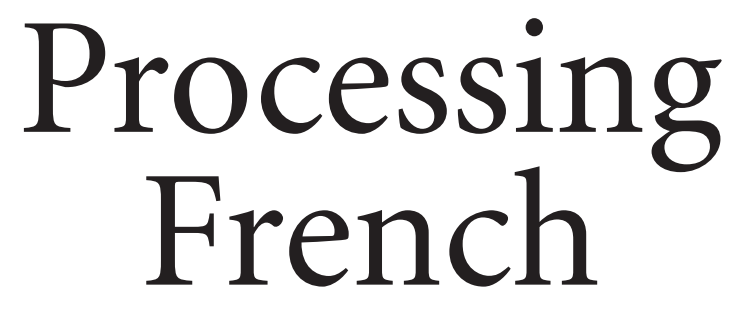

a psycholinguistic perspective

PETER GOLATO

University of Illinois at Urbana-Champaign

Yale University Press New Haven and London 
Copyright $\odot 2006$ by Yale University.

All rights reserved.

This book may not be reproduced, in whole or in part, including illustrations, in any form (beyond that copying permitted by Sections 107 and 108 of the U.S. Copyright Law and except by reviewers for the public press), without written permission from the publishers.

Publisher: Mary Jane Peluso

Editor: Ann-Marie Imbornoni

Editorial Assistant: Brie Kluytenaar

Production Controller: Karen Stickler

Designer: Sonia Shannon

Marketing Manager: Timothy Shea

Set in Minion type by Integrated Publishing Solutions.

Printed in the United States of America.

Library of Congress Cataloging-in-Publication Data

Golato, Peter, 1965-

Processing French : a psycholinguistic perspective / Peter Golato

p. $\quad \mathrm{cm}$.

Includes bibliographical references and index.

ISBN 0-300-10835-4 (pbk. : alk. paper)

1. French language-Psychological aspects.

2. Psycholinguistics. I. Title.

PC2073.G57 2006

440 '.19—dc22 2005016027

A catalogue record for this book is available from the British Library.

The paper in this book meets the guidelines for permanence and durability of the Committee on Production Guidelines for Book Longevity of the Council on Library Resources. 